\title{
Local Level Service Delivery, Decentralisation And Governance: A Comparative Study Of Uganda, Kenya And Tanzania
}

\section{Per Tidemand}

DEGE Consult Limited, Tanzania

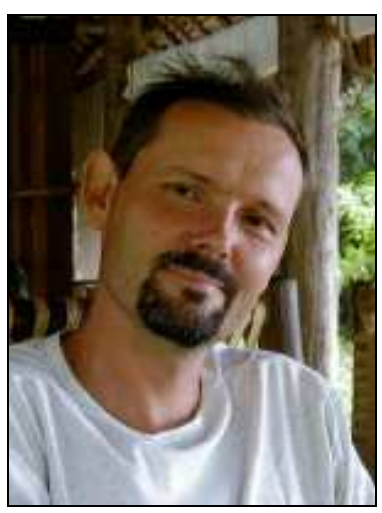

Key words: decentralisation, local governance, local level service delivery, transparency, participation, user groups, privatisation

\section{Introduction}

This paper summarises key findings from a comprehensive analysis commissioned by the Japan International Cooperation Agency (JICA) of the nature of decentralisation in the three East African countries: Kenya, Uganda and Tanzania.

The specific objectives of the study were:

- Provide a basic comparative analysis of the forms and processes of decentralisation reforms in the three countries

- Analyse the specific modalities in the three countries for local service delivery planning and provision within the three sectors of basic education, primary health care and agricultural extension, with a particular emphasis on rural areas. 
- Explore the impact of the specific forms of decentralisation and local level service delivery arrangements in terms of efficiency, accountability (transparency) and democratic process (participation).

\section{Scope of decentralisation reforms studied}

The study analysed the various forms of decentralisation ${ }^{1}$ as they have been interpreted and applied in the three East African countries for local level service delivery of (basic) education, (primary) health care and agriculture. In practice this includes:

- Examples of devolved systems of service delivery - in principle for all three sectors in both Uganda and Tanzania as local governments are primarily responsible for these services.

- Examples of deconcentrated delivery - the most dominant form for local service delivery in Kenya.

- Some examples of partial privatisation - most prominently a feature of the reforms of the systems for delivery of agricultural services.

- In all sectors various forms of direct decentralisation to user groups - school management committees, health user management committees and farmers groups.

\section{Legal and Policy Framework}

\section{Current reform challenges for decentralisation by devolution}

Uganda has by far the most clearly outlined local government legislation, which furthermore is embedded in great detail in the Constitution. In Uganda local governments manage approximately $25 \%$ of public expenditure and have wide-ranging service delivery responsibilities. The system of local governance and service delivery in Uganda exhibits a remarkable degree of devolution compared to other sub-Saharan African countries. It has, for instance, one of the most devolved systems of human resource management whereby local governments through their respective District Service Commissions locally recruit their staff. Approximately $70 \%$ of all public servants are in this manner locally hired and managed. However, with recent Constitutional amendments in 2006 that centralised appointment of local governments' Chief Executive Officers, the abolishing of several local taxes (2004), as well as a new centralised system of payment of councillors, the government of Uganda has recently moved towards re-

\footnotetext{
${ }^{1}$ The basic concepts of devolution, deconcentration, etc are assumed known to the reader - however concepts are defined in the main study quoted above.
} 
centralisation of the public service. The system of local government has arguably also been weakened by introduction of unfunded added layers, including an additional regional tier and continued creation of new districts. A recently developed Local Government Sector Investment Plan and associated policy statements may assist in coordinating different projects and external support for decentralisation reforms, but does not provide for any renewed policy commitment to decentralisation by devolution.

In mainland Tanzania, reforms were embarked upon in 1998, but are not yet fully reflected in revised legislation. Substantive progress can be noted in recent years regarding development of fiscal transfer systems and capacity building of local governments; the system of local service delivery is gradually being devolved with increased central government funding. Local governments in Tanzania currently manage approximately $22 \%$ of public expenditure. However, the scope of local autonomy of local governments has not expanded in the last decade, and in particular the area of human resource management appears unlikely to be devolved in the near future - in spite of the 1998 policy intentions.

The Tanzanian reforms do not include Zanzibar, where local governments play a rather marginal role and operate in parallel to strong regional and district administrations.

In Kenya, the Local Government Act has remained relatively unchanged for a long period. It gives local governments a very limited mandate and they have few staff and manage only approximately $4 \%$ of total public expenditures. A 2005 constitutional draft proposed significant devolution. Although the overall constitutional proposal was rejected in 2005, it is still a common view in Kenya that the articles pertaining to decentralisation made sense. However, given the current political deadlock in Kenya a new legal framework for local government is unlikely in the immediate future. In their present form, local governments are becoming increasingly irrelevant for delivery of local services. In the institutional vacuum, sectors have gone ahead and established structures to effectively decentralise service delivery and promote community involvement in the planning, implementation and monitoring of local level service delivery, just as a Constituency Development Fund has initiated processes of crosssectoral sub-district and community level planning. These moves may all feed into ultimate reforms, but currently lead to significant problems of cross-sector coordination and problems with linking recurrent and capital investments. 


\section{Division of sector service responsibilities across levels of government}

Major service provision responsibilities are devolved to local governments in mainland Tanzania and Uganda, whereas their counterparts in Kenya and Zanzibar have very limited mandates. The situation within each of the major local service delivery sectors is summarised in the table below.

Table 1: Extent of Devolution of Key Sector Responsibilities to Local Governments (LGs)

\begin{tabular}{|l|l|l|l|}
\hline Sector & Kenya & Tanzania Mainland & Uganda \\
\hline Education & $\begin{array}{l}\text { Minor role. Seven of } \\
\text { the major urban LGs } \\
\text { are designated as } \\
\text { 'education } \\
\text { authorities'; the } \\
\text { remaining LGs play } \\
\text { no major role in } \\
\text { provision } \\
\text { educational services. }\end{array}$ & $\begin{array}{l}\text { Primary education in } \\
\text { principle devolved - } \\
\text { however teachers } \\
\text { recruited by TSC. Yet } \\
\text { no specific role in } \\
\text { secondary education. }\end{array}$ & $\begin{array}{l}\text { Primary education } \\
\text { fully devolved to LGs; } \\
\text { secondary education } \\
\text { still with central } \\
\text { government. }\end{array}$ \\
\hline Health & $\begin{array}{l}\text { No major role for LGs } \\
- \text { mainly undertaken } \\
\text { by Ministry of Health. }\end{array}$ & $\begin{array}{l}\text { LGs responsible for } \\
\text { primary health care. } \\
\text { Hospitals managed } \\
\text { by health boards. }\end{array}$ & $\begin{array}{l}\text { LGs responsible for } \\
\text { primary health care } \\
\text { and district hospitals. }\end{array}$ \\
\hline Agriculture & No major role for LGs. & $\begin{array}{l}\text { LGs are legislatively } \\
\text { main responsible - } \\
\text { but resources largely } \\
\text { allocated through } \\
\text { central programmes. }\end{array}$ & $\begin{array}{l}\text { LGs are main } \\
\text { responsible, } \\
\text { current efforts are } \\
\text { made for privatising } \\
\text { services. }\end{array}$ \\
\hline
\end{tabular}

As is evident from the table, in Uganda and Tanzania responsibilities for local service delivery in the three key sectors analysed in this study (primary health, primary education and agricultural extension) are firmly placed with local government. In Kenya, the system is substantially more complex. Central government has put in place a general deconcentrated administration (the district system) with broad local planning responsibilities, plus separate sector systems that are mainly responsible through a deconcentrated structure for service delivery in rural areas. In addition, the $\mathrm{NGO}$ /private sector play a very significant role in Kenya, whilst the recently introduced system for management of the Constituency Development Fund is becoming increasingly important, and now covers the largest part of locally available development funding - primarily spent in sectors such as education, health and agriculture. 


\section{Impact of (sector) decentralisation on governance}

The three sectors analysed in the study interact in very different ways with the local governments. Although all sectors are operating broadly in adherence to the various local government legislation and policies, they also aim in different ways to enhance sectorspecific policies and strategies. An overall finding of the study is that sector and local government planning to a large extent continue to operate in parallel even in Tanzania and Uganda, where substantive devolution has been pursued. This is foremost reflected in how public service delivery is financed. In both countries, fiscal transfers account for almost $95 \%$ of rural local governments' budgets. The specific architecture of local government fiscal transfers determine in practice how plans and budgets are developed and implemented as each grant is accompanied with separate planning guidelines.

In Uganda and Tanzania, only the LGDP/LGCDG ${ }^{2}$ provide incentives for broader governance issues such as cross-sector planning, broad-based citizen participation, and general local accountability, whereas the earmarked grants in the three sectors and their focus on upwards accountability to the central government rather than downwards to the citizens, have tended to undermine local government autonomy and involvement of citizens in decision-making and supervision.

The impact of the sector-specific efforts for decentralisation on governance has in a broad sense been positive in enhancing citizens participation in planning and delivery of services through sector-specific user groups, but negative in terms of citizen participation in cross sector planning and budgeting through their local government councils. More specifically, the study concludes as follows.

- Transparency and equity is generally pursued through local government reforms by formula-based grant allocation of fiscal resources to local governments. Sectors are gradually following suit, with education sectors being most consistent. However, allocating fiscal resources for (sector) staff has proved difficult to implement in accordance with agreed decentralisation principles, and substantive regional variation still persists.

- Representative democracy through participation of elected councillors at district level in planning, budgeting and management of sector issues is partially achieved in Uganda and Tanzania, whilst participation of elected leaders at the

\footnotetext{
${ }^{2}$ Two modalities for discretionary development funding: LGDP = Local Government Development Programme and LGCDG = Local Government Capital Development Grant.
} 
sub-district level is supported by education and agricultural sectors - but not the health sector - in those countries.

- User groups (at the facility or delivery point level) have been created in all three sectors to manage selected parts of service delivery planning, budgeting and implementation. In Kenya this is often as response to the non-performance of the representative local councils; in Tanzania and Uganda it is more as a supplement to the role of councils. The functions given to these groups differ substantially across sectors and countries. In the education sector school management committees now manage a substantial part of the budgets. In the health sector, the involvement of user groups is especially found at lower health units and generally is far less pronounced, but emerging. These user groups and the decentralisation of sector responsibilities and funding to them have enhanced direct community participation in service delivery, and in the education sector there is some evidence that this improves effectiveness, although the effectiveness of participation seems to decline when user fees are abolished, which in turn possibly leads to inefficiencies. ${ }^{3}$ While user groups in health and education provide inputs to the management of a public service, in agriculture the planned and ongoing extension reforms aim for a more radical rearrangement of sector service delivery arrangements: farmers are organised in groups and strengthened to manage contracts with private service providers.

\section{Impact of (sector) decentralisation on service delivery}

Decentralisation has not been implemented as the only mode of service delivery and multiple external factors have impacted on the level of service delivery over the past 5-10 years. Furthermore, the modes of decentralisation are not found in the 'pure form' in any of the countries, in the sense that hybrid models have been practiced with features of centralised and decentralised service delivery. With these caveats the study concludes only tentatively on the impact of decentralisation reforms in the three sectors.

The overall conclusion is that only education sectors to date can register major service delivery achievements. These achievements have foremost been quantitative (increased enrolment etc) and are primarily explained by the sector's strong policy focus (universal primary education) and increased public budgets. Agricultural extension is the most

\footnotetext{
${ }^{3}$ Fieldwork in Uganda indicated higher level of participation and more efficient use of resources in private schools in Mayuge District compared to government schools.
} 
disputed of the three services analysed. In Uganda the reforms of extension services have been most radical in pursuit of a privatised system. Sector evaluations of their impact are non-conclusive: some local success stories are noted but sustainability is questioned.

The potential impact of decentralised service delivery through local governments in Uganda and Tanzania is not fully realised because sector funding modalities and sector control of staff remain so persistent. Certain aspects of decentralisation reforms in the two countries have facilitated service improvements - for example the systems for common local financial management and coordination. The absence of similar systems in Kenya is widely recognised as a constraining factor, and the current multiple institutional arrangements are considered more wasteful, reflected in less cross- sector coordination and more problematic linkages between recurrent and capital budgets - especially for infrastructure financed through the Constituency Development Fund.

\section{References}

Japan International Cooperation Agency 2008, Decentralised Service Delivery in East Africa A Comparative Study of Uganda, Tanzania and Kenya, Research Group, Institute for International Cooperation, Tokyo, accessed 08 May 2009, <http://www.jica.go.jp/english/publications/reports/study/topical/africa/pdf/001.pdf>

Japan International Cooperation Agency 2008, Local Level Service Delivery, Decentralisation and Governance - A Comparative Study of Uganda, Kenya and Tanzania Education, Health and Agriculture Sectors KENYA REPORT, Research Group, Institute for International Cooperation, Tokyo, accessed 08 May 2009, <http://www.jica.go.jp/english/publications/reports/study/topical/kenya/pdf/000.pdf>

Japan International Cooperation Agency 2008, Local Level Service Delivery, Decentralisation and Governance - A Comparative Study of Uganda, Kenya and Tanzania Education, Health and Agriculture Sectors TANZANIA REPORT, Research Group, Institute for International Cooperation, Tokyo, accessed 08 May 2009, <http://www.jica.go.jp/english/publications/reports/study/topical/tanzania/pdf/001.pdf $>$

Japan International Cooperation Agency 2008, Local Level Service Delivery, Decentralisation and Governance - A Comparative Study of Uganda, Kenya and Tanzania Education, Health and Agriculture Sectors UGANDA REPORT, Research Group, Institute for International Cooperation, Tokyo, accessed 08 May 2009, <http://www.jica.go.jp/english/publications/reports/study/topical/uganda/pdf/000.pdf>

Japan International Cooperation Agency 2008, Local Level Service Delivery, Decentralisation and Governance - A Comparative Study of Uganda, Kenya and Tanzania Education, Health and Agriculture Sectors SYNTHESIS REPORT, Research Group, Institute for International Cooperation, Tokyo, accessed 08 May 2009,

<http://www.jica.go.jp/english/publications/reports/study/topical/synthesis/pdf/001.pdf> 